\title{
Pembuatan Video Tutorial Table Manner Sebagai Media Pembelajaran Bahasa Inggris Untuk Siswa SMK Negeri 3 Jember
}

\author{
Agus Setia Budi \\ Jurusan Bahasa, Komunikasi dan Pariwisarta, Politeknik Negeri Jember \\ gustibudeyahoo.com \\ Suyik Binarkaheni \\ ${ }^{\#}$ Jurusan Bahasa, Komunikasi dan Pariwisarta, Politeknik Negeri Jember \\ sbinarkaheni@gmail.com
}

\begin{abstract}
Kegiatan Pengabdian kepada Masyarakat ini dilaksanakan di SMK Negeri 3 Jember. Kegiatan ini dilaksanakan untuk memberikan kontribusi kepada mitra dalam rangka pengembangan kualitas pendidikan dan pengajaran. Tujuan dari kegiatan pengabdian ini adalah unutk mengembangkan media pembelajaran Bahasa Inggris yaitu video tutorial tentang table manner yang efektif dan menarik bagi siswa SMK Negeri 3 Jember, memanfaatkan media dalam proses pembelajaran bagi siswa SMK Negeri 3 Jember dan eningkatkan minat dan prestasi belajar Bahasa Inggris, khususnya teantang table manner, para siswa SMK Negeri 3 Jember. Kegiatan ini dilaksanakan selama empat bulan dengan melibatkan guru Bahasa Inggris dan para siswa SMK Negeri 3 Jember. Luaran yang dihasilkan dari kegiatan ini adalah media pembelajaran dalam bentuk video tutorial manner sebagai media pembelajaran Bahasa Inggris.
\end{abstract}

Keywords - Pembuatan, Video Tutorial, Media Pembelajaran

\section{Pendahuluan}

Era globalisasi adalah sebuah fenomena yang mana hubungan sosial sudah meluas dan mendunia ( lobal). Sehingga era globalisasi dapat dimaknai sebagi waktu atau masa dimana segala aspek kehidupan sudah mendunia dan meluas. Globalisasi berdampak pada beberapa aspek kehidupan seperti bidang politik, teknologi, wawasan, budaya dan ekonomi terutama dalam bidang bisnis.

Bisnis yang berskala internasional meliputi beberapa aspek komunikasi tertentu mulai dari bahasa sampai etika atau nilai yang digunakan dalam berkomunikasi. Karena mempelajari dan menggunakan bahasa tidak terlepas dari budaya yang di dalamnya terkandung etika dan nilai. Bahasa yang digunakan dalam dunia bisnis memiliki etika atau nilai tertentu yang harus di pahami dan dimengerti oleh pelaku bisnis.

Kegiatan bisnis sering dilaksanakan di sebuah hotel atau restauran. Karena hotel dan restauran biasanya akan menyediakan fasilitas-fasilitas umtuk kegiatan bisnis seperti penginapan (accomodation), ruang pertemuan (meeting room) dan retauran (restaurant). Sehingga apabila kegiatan bisnis dilaksanakan di hotel maka tidak terlepas dari acara perjamuan makan. Sudah menjadi hal yang umum bahwa kegiatan bisnis biasanya dilakukan di atas meja. Kegiatan makan yang menyertai kegiatan bisnis tersebut dilakukan dengan mengikuti aturan tertentu yang biasa disebut dengan etika makan (table manner).

Sekolah Menengah Kejuruan Negeri 3 Jember adalah sekolah menengah vokasi yang fokus untuk mengajarkan siswanya dalam bidang pariwisata yang salah satunya adalah tentang perhotelan. Dalam proses pembelajaran yang berkaitan dengan kegiatan bisnis yang dilakukan di hotel, maka siswa akan diajarkan pula tentang kegiatan makan yang dilakukan oleh pelaku bisnis yang mengikuti etika bisnis (table manner). Table manner diajarkan kepada siswa dengan tujuan adalah memberi pengetahuan kepada siswa tentang semua kegiatan yang dilakukan di hotel yang salah satunya adalah table manner 
tersebut. Sehingga diharapkan para siswa jika nantinya terjun di dunia kerja khususnya di bidang perhotelan, maka mereka sudah tidak asing lagi dengan istilah disebut tabble manner.

Menurut hasil studi pendahuluan (preliminary study) yang dilakukan di sekolah tersebut, yaitu berupa wawancara (interview) dengan beberapa guru mata pelajaran yang berkaitan dengan perhotelan serta guru bahasa Inggris, diketahui bahwa sekolah mengalami kesulitan dalam menyampaikan materi pembelajaran tentang kegiatan di hotel dan restoran. Hal ini disebabkan karena kurang adanya media yang tepat untuk menyampaikan materi tersebut. Para siswa sebagian besar mengalami kesulitan dalam mempelajari dan memahami materi tentang etika makan (table manner) karena penyajian materi diberikan secara konvensional atau ceramah dan penggunaan gambar yang tidak bergerak yang menyertai penjelasan yang ada di buku. Cara tersebut dirasa kurang efektif karena tidak dapat menarik perhatian siswa dan materi tersebut sulit diingat oleh siswa.

Untuk mengatasi masalah tersebut, diperlukan media yang menarik untuk menyampaikan materi tersebut sehingga materi yang diberikan akan terasa menarik dan mudah dimengerti serta dipahami oleh siswa. Media pembelajaran merupakan faktor yang paling dibutuhkan untuk menunjang keberhasilan proses pembelajaran bahasa Inggris. Seperti yang dinyatakan oleh Miarso (2005) bahwa media sebagai segala sesuatu yang digunakan untuk menyalurkan pesan serta dapat merangsang pikiran, perasaan, perhatian, dan kemauan peserta didik sehingga dapat mendorong terjadinya proses belajar yang disengaja, bertujuan dan terkendali. Definisi tersebut diperkuat oleh Rohmat (2010) yang menyatakan bahwa media berfungsi untuk menghindari hambatan atau gangguan komunikasi dalam proses belajar mengajar dan meningkatkan minat dan motivasi siswa dalam belajar. Ada beberapa jenis media pembelajaran (instructional media) yang dapat digunakan oleh guru dalam proses belajar mengajar seperti yang disebutkan oleh Harmer (2007) yaitu benda-benda nyata (realia), gambar (pictures), buku (coursebooks), papan tulis (boards), OHP (Overhead Projector), bagan (flipcharts) dan presentasi dengan menggunakan teknologi komputer (computer-based presentation technology).

Media yang tepat untuk menyampaikan materi tersebut adalah video. Karena menurut Jewitt (2012) bahwa Video dapat memberikan gambaran yang bagus dari suatu peristiwa dengan baik dan jelas baik yang berupa tatapan, ekspresi, postur tubuh, sikap, dan sebagainya. Video adalah media yang tepat untuk memberikan gambaran tentang kegiatan table manner karena melalui video siswa dapat melihat postur dan sikap tubuh secara jelas ketika berada di atas meja makan. Selain itu video juga tahan lama, mudah dibuat dan direkam serta digandakan kemudian dibagikan kepada yang membutuhkan. Apabila diinginkan maka dapat diputar berulang kali, gerakan yang ada di dalam video dapat dibuat lambat atau cepat sehingga dapat mempermudah pemahaman terhadap materi yang disampaikan melalui video.

\section{TARGET DAN LUARAN}

A. Target

Target yang ingin dicapai dalam kegiatan pengabdian kepada masyarakat ini adalah sebagai berikut:

1. Mengembangkan media pembelajaran Bahasa Inggris yaitu video tutorial tentang table manner yang efektif dan menarik bagi siswa SMK Negeri 3 Jember.

2. Memanfaatkan media dalam proses pembelajaran bagi siswa SMK Negeri 3 Jember.

3. Meningkatkan minat dan prestasi belajar Bahasa Inggris, khususnya teantang table manner, para SMK Negeri 3 Jember.

\section{B. Luaran}

Luaran dari kegiatan pengembangan media pembelajaran Bahasa Inggris ini antara lain sebagai berikut:

1. Media pembelajaran berupa video tutorial tentang table manner yang dapat membuat proses pembelajaran di SMK Negeri 3 Jember menjadi lebih efektif dan menarik.

2. Peningkatan minat dan prestasi belajar bahasa Inggris khususnya pada pelajaran yang berkaitan dengan perhotelan SMK Negeri 3 Jember.

\section{METODE PELAKSANAAN}

Pelaksanaan kegiatan pengembangan media pembelajaran Bahasa Inggris ini adalah sebagai berikut:

\section{A. Studi Pendahuluan}

Sebelum pengembangan media pembelajaran dilaksanakan, terlebih dahulu dilakukan studi pendahuluan (preliminary studi) melalui wawancara (interview) dan observasi (observation). Wawancara dilakukan dengan Kepala Sekolah, dan guru bahasa Inggris serta guru mata pelajaran yang berkaitan dengan perhotelan pada SMK Negeri 3 Jember. Kegiatan studi pendahuluan tersebut dilaksanakan untuk memperoleh data tentang kondisi sekolah secara umum, kebutuhan siswa, proses pembelajaran, serta media yang dipergunakan dan yang dibutuhkan dalam proses pembelajaran, Observasi dilakukan untuk memperoleh data tentang sikap siswa dan media pembelajaran yang dipergunakan dalam proses pembelajaran. Studi pendahuluan ini dilakukan agar kegiatan pengabdian kepada masyarakat ini dapat memenuhi kebutuhan siswa pada SMK Negeri 3 Jember sehingga dapat memberi kontribusi dalam meningkatkan minat dan prestasi belajar siswa.

\section{B. Pengembangan Media Pembelajaran}

Informasi yang diperoleh dari studi pendahuluan tersebut menjadi dasar untuk menentukan kegiatan pengabdian kepada masyarakat, yaitu pengembangan media 
pembelajaran berupa video tutorial tentang table manner dalam bahasa Inggris. Pengembangan media pembelajaran ini mengikuti prosedur yang disampaikan oleh Lyver (2001) tentang pembuatan video yang meliputi langkah-langkah sebagai berikut:

1. Menentukan target penonton

2. Menyusun anggaran

3. Menentukan rencana produksi

4. Membuat Story Board

5. Memeriksa peralatan dan mengatur lokasi pengambilan gambar

6. Pengambilan gambar

7. Pengeditan gambar

8. Audio Dub

9. Uji Coba

10. Burning

Dengan memperhatikan prinsip-prinsip pengembangan media pembelajaran tersebut, diharapkan media pembelajaran yang dikembangkan dalam kegiatan pengabdian kepada masyarakat ini tidak saja dapat memenuhi kebutuhan siswa untuk meningkatkan tingkat pemahaman siswa terhadap materi yang diberikan, tetapi juga dapat membuat proses belajar menjadi lebih mudah dan menarik sehingga dapat meningkatkan minat siswa dalam mengikuti kegiatan pembelajaran.

\section{HASIL DAN PEMBAHASAN}

Hasil dari kegiatan pengabdian kepada masyarakat dalam bentuk pengembangan media pembelajaran Bahasa Inggris dalam bentuk video tutorial untuk siswa SMK Negeri 3 Jember adalah sebagai berikut:

\section{A. Analisis Kebutuhan}

Analisis kebutuhan untuk kegiatan ini dilakukan sebelum pelaksanaan pengembangan media pembelajaran Bahasa Inggris bagi siswa SMK Negeri 3 Jember. Metode yang digunakan dalam melakukan analisis kebutuhan ini adalah wawancara dan observasi. Wawancara dilakukan dengan kepala sekolah dan guru Bahasa Inggris pada SMK Negeri 3 Jember untuk memperoleh data tentang jumlah dan karakteristik siswa, proses pembelajaran Bahasa Inggris, serta media yang dipergunakan dan yang dibutuhkan dalam proses pembelajaran Bahasa Inggris. Observasi dilakukan untuk memperoleh data tentang sikap siswa dan media pembelajaran yang dipergunakan dalam proses pembelajaran Bahasa Inggris.

Dari hasil wawancara, diperoleh informasi mengenai jumlah dan karakteristik siswa dalam proses pembelajaran Bahasa Inggris, media yang tersedia dan digunakan di SMK Negeri 3 Jember, serta media tambahan yang dibutuhkan oleh para siswa SMK Negeri 3 Jember. Dalam belajar Bahasa Inggris, para siswa hanya menggunakan materi berupa buku teks yang ada di sekolah. Oleh karena itu, para siswa membutuhkan media pembelajaran yang lebih menarik untuk meningkatkan minat belajar mereka.

Dari hasil observasi, diperoleh data tentang proses, sikap siswa, serta media yang digunakan dalam pembelajaran Bahasa Inggris. Dalam proses pembelajaran, para siswa kurang memiliki motivasi untuk belajar Bahasa Inggris. Sebagian dari mereka kurang berminat belajar Bahasa Inggris sehingga pada saat proses pembelajaran berlangsung, sebagian besar siswa kurang memperhatikan dan bersikap pasif. Oleh karena itu, diperlukan media pembelajaran yang lebih menarik untuk meningkatkan motivasi siswa dan membantu mereka dalam belajar Bahasa Inggris. Berdasarkan hasil analisis kebutuhan tersebut, media pembelajaran yang perlu dikembangkan dan dapat menarik perhatian siswa adalah media audio visual dalam bentuk video tutorial. Video tutorial tersebut berisi materi Bahasa Inggris dengan topic yang disesuaikan dengan bidang keilmuan mereka yaitu tentang table manner.

\section{B. Pengembangan Media Pembelajaran}

Ada beberapa langkah dalam pembuatan Video Tutorial Table Manner sebagai Media Pembelajaran Bahasa Inggris untuk Siswa SMK Negeri 3 Jember. Langkahlangkah tersebut antara lain adalah sebagai-berikut:

\section{Menentukan target penonton}

Menentukan target penonton adalah langkah pertama yang dilakukan dalam pembuatan video tutorial ini. Siswa SMK Negeri 3 Jember ditentukan sebagai penonton video tutorial ini karena di sekolah tersebut terdapat jurusan perhotelam dan tata boga. Dalam wawancara dengan guru salah satu guru Bahasa Inggris di sekolah tersebut, diperoleh informasi bahwa media pembelajaran yang menarik seperti video tutorial sangat diperlukan bagi siswa dengan tujuan untuk meningkatkan motivasi mereka dalam belajar Bahasa Inggris. Terlebih lagi jika video tutorial yang digunakan dalam pembelajaran Bahasa Inggris tersebut menyajikan materi dengan topik yang sesuai dengan bidang mereka yaitu bidang perhotelan dan tata boga. Sehingga video tutorial tentang table manner ini sangat cocok digunakan sebagai media pembelajaran Bahasa Inggris karena kontennya yang cocok dengan bidang mereka, yang paling penting video ini disajikan dalam Bahasa Inggris .

\section{Menyusun anggaran}

Langkah kedua adalah menyusun anggaran. Dalam hal ini pelaksana pengabdian kepada masyarakat menyusun anggaran pembutan video. Anggaran tersebut meliputi biaya yang digunakan dalam melaksanakan studi awal, yaitu biaya perjalan untuk melaksanakan wawancara dengan pihak mitra pengabdian dan observasi di tempat pengabdian. Anggaran kedua berkaitan dengan biaya produksi yang meliputi biaya yang digunakan dalam pengadaan alat dan bahan yang digunakan dalam pengambilan gambar dan pengeditan video, termasuk honorarium untuk kameramen dan editor. 


\section{Menentukan rencana produksi}

Langkah ketiga adalah membuat rencana produksi. Pelaksana pengabdian menyusun jadwal untuk observasi lokasi, menghubungi kameramen dan jadwal pengambilan gambar. Berdasarkan jadwal yang telah disusun, pembuatan video tutorial dimulai pada tanggal 25 Agustus 2016 sampai dengan tanggal 31 Oktober 2016.

\section{Membuat Story Board}

Langkah ke empat adalah membuat story board. Tory board ini berisi sketsa gambar yang berkaitan dengan video tutorial tentang table manner. Sketsa gambar ini digunakan oleh kameramen sebagai panduan dalam pengambilan gambar. Sketsa gambar ini dibuat dengan menggunakan komputer khususnya dengan program Microsoft Word menggunakan shape tools. Selain berisi sketsa gambar, story board juga berisi deskripsi tentang sketsa gambar tersebut, narasi untuk setiap gambar dan durasi waktu setiap bagian penayangan gambar.

5. Memeriksa peralatan dan mengatur lokasi pengambilan gambar

Langkah kelima adalah memeriksa peralatan yang digunakan untuk membuat video table manner seperti kamera, tripod, pencahayaan, meja, kursi, alat tulis dan fasilitas lain. Semua peralatan yang digunakan dalam pembuatan video tutorial tersebut adalah peralatan yang ada di laboratorium Bahasa Inggris. Kemudian dilanjutkan dengan mengatur lokasi pengambilan gambar yaitu dengan memilih ruangan yang cukup pencahayaannya agar dapat menghasilkan gambar video yang bagus. Ruangan yang digunakan dalam pengambilan gambar adalah ruangan Students Access Center (SAC) di Unit Pelayanan dan peltaihan (UP2B) Politeknik Negeri Jember.

\subsubsection{Pengambilan gambar}

Langkah ke enam adalah mengambil gambar berdasarkan story board. Pelaksana pengabdian melakukan pengambilan gambar tentang kegiatan table manner. Kegiatan table manner dalam pengambilan gambar tersebut melibatkan empat siswa SMK Negeri 3 Jember. Mereka berperan sebagai aktris pemeran peserta table manner di dalam video tersebut. Dalam proses pengambilan gambar tersebut mereka dapat memerankan adegan sebagai peserta table manner dengan baik sehingga proses pengambilan gambar tersebut dapat berjalan dengan lancar.

\subsubsection{Pengeditan gambar}

Setelah pengambilan gambar, langkah selanjutnya adalah mengedit video dengan menggunakan program movie maker. Dalam hal ini gambar yang kurang sesuai dihilangkan dan diganti dengan gambar yang sesuai. Selanjutnya gambar dilengkapi dengan latar belakang suara atau musik agar menjadi lebih menarik. Gambar yang digunakan dalam video tutorial tersebut adalah hasil pengambilan gambar langsung dalam simulasi kegiatan table manner yang diikuti oleh siswa SMK Negeri 3 Jember dikombinasikan dengan beberapa gambar dari internet. Gambar-gambar tersebut meliputi gambar yang sesuai dengan tema yang ada pada video tutorial tersebut yang meliputi sejarah table manner (history of table manner), peralatan table manner (equipment), pengetahuan tentang menu dalam table manner (menu knowledge) dan etika table manner (etiquette of table manner).

\section{Audio Dub}

Langkah ini dilakukan dengan memasukkan suara seseorang untuk memberikan keterangan dan penjelasan pada gambar yang ditampilkan. Dalam video tersebut pelaksana pengabdian melibatkan siswa SMK Negeri 3 Jember baik dalam pengambilan gambar maupun untuk pengisian suara/narasi (Audio Dub). Sebagai narator, dipilih salah satu siswa sekolah tersebut yang mempunyai kemampuan Bahasa Inggris bagus terutama dalam hal pengucapan kata atau kalimat dalam Bahasa Inggris (pronunciation). Proses audio dub diawali dengan perekaman suara yaitu berupa narasi yang ada di story board yang dibaca oleh seorang narator yaitu salah satu siswa SMK Negeri 3 Jember. Kemudian hasil rekaman tersebut dimasukkan ke dalam video dengan mencocokan antara suara narasi dengan gambar dalam video.

\section{Uji Coba}

Setelah pembuatan video tutorial selesai, maka selanjutnya video tersebut ditunjukkan ke guru Bahasa Inggris dan sekaligus diuji cobakan dalam proses pembelajaran Bahasa Inggris kepada siswa yang ada di SMK Negeri 3 Jember. Video tersebut juga ditunjukkan kepada pihak lain yang memahami tentang pembuatan video untuk mendapatkan masukan dan saran untuk memperoleh hasil yang lebih baik. Hasil uji coba yang pertama menunjukkan bahwa siswa sangat antusias dalam mengikuti pelajaran Bahasa Inggris dengan digunakannya video tutorial tersebut sebagai media pembelajaran. Karena video tersebut menampilkan gambar-gambar yang dapat menarik perhatian mereka, terlebih pemeran dalam video tersebut adalah beberapa siswa diantara mereka. Mereka juga dapat menyerap materi yang ada dalam video dengan mudah karena materi yang ada dalam video tersebut disajikan dengan jelas dan sistematis. Walaupun begitu pada uji coba yang pertama tersebut, ditemukan beberapa kekurangan pada video tersebut. Bagian-bagian yang kurang sempurna tersebut antara lain adalah ada beberapa narasi yang kurang jelas pengucapannya, penayangan gambar terlalu cepat sehingga siswa sulit memahaminya, beberapa gambar kutang sesuai dengan bunyi narasi dan beberapa kekurangan yang lain. Beberapa kekurangan yang ditemukan pada uji coba yang pertama menjadi dasar evaluasi untuk perbaikan video sehingga pada akhirnya memperoleh hasil yang sesuai dengan yang diharapkan. Setelah diadakan perbaikan, maka selanjutnya diadakan uji coba yang kedua. Pada uji coba yang kedua ini, penggunaan video tutorial tersebut sebagai 
media pembelajaran Bahasa Inggris berjalan lebih baik dari pada pada uji coba yang pertama.

\section{Burning}

Langkah yang terakhir adalah dalam pembuatan video tutorial ini adalah mengkopi video ke dalam Compact Disk (CD). Langkah ini dilakukan dengan menggunakan Nero Software. Video tersebut pada akhirnya diserahkan ke SMK Negeri 3 Jember sebagai mitra kegiatan pengabdian ini dan selanjutnya akan digunakan sebagai media dalam proses pembelajaran yang ada di sekolah tersebut.

\section{KESIMPULAN DAN SARAN}

\section{A. Kesimpulan}

Berdasarkan hasil dan pembahasan kegiatan pengadian kepada masyarakat dalam bentuk pengembangan media pembelajaran berupa video tutorial table manner untuk pembelajaran Bahasa Inggris pada bab sebelumnya dapat disimpulkan bahwa:

1. Siswa SMK Negeri 3 Jember harus dorong untuk belajar Bahasa Inggris sebagai bahasa internasional. Hal ini perlu dilakukan mengingat bahasa Inggris merupakan bahasa asing sekaligus bahasa internasional yang wajib dipelajari dan kuasai oleh para siswa sebagai bekal mereka untuk memasuki dunia kerja setelah mereka lulus nanti.

2. Peningkatan minat belajar Bahasa Inggris dapat dilakukan dengan penggunaan media yang menarik sesuai dengan kebutuhan dan bidang ilmu para siswa di SMK Negeri 3 Jember.

3. Pengembangan media pembelajaran Bahasa Inggris yang menarik bagi siswa di SMK Negeri 3 Jember dapat berupa video tutorial yang berkaitan dengan topik yang sesuai dengan bidang keilmuan mereka.

B. Saran

Saran yang diberikan berdasarkan kesimpulan di atas adalah sebagai berikut:

1. Para pengelola SMK Negeri 3 Jember dalam hal ini kepala sekolah selalu berupaya untuk terus meningkatkan minat dan motivasi belajar Bahasa Inggris siswa, mengingat pentingnya penguasaan Bahasa Inggris sebagai alat komunikasi internasional.

2. Para guru Bahasa Inggris di SMK Negeri 3 Jember hendaknya selalu berupaya untuk menciptakan suasana belajar yang menyenangkan misalnya melalui pemanfaatan media pembelajaran yang sesuai dengan kebutuhan dan bidang ilmu mereka.

3. Politeknik Negeri Jember hendaknya selalu menjalin dan memelihara kerjasama yang baik dengan masyarakat sekitar sehingga dapat memberikan kontribusi yang nyata dalam pengembangan masyarakat sebagai salah satu pelaksanaan Tri Dharma Perguruan Tinggi.

\section{DAFTAR PUSTAKA}

Harmer, J. (2007). The Practice of English Language Teaching (4 ed.).Cambridge: Pearson Education.

Jewitt, C. 2012. National Centre for Research Methods Working Paper. An Introduction to Using Video for Research. London: Institute of Education. $\quad$ Electronic-book http://eprints.ncrm.ac.uk/2259/4/NCRM workingpaper 0312.pdf (Accessed on Sunday 1st November 2015 at 07:30 p.m.)

Lyver D. 2001. Basics of the Video Production Diary. Electronic-Book. http://gen.lib.rus.ec/search.php?req=Lyver+D.+2001.+Basics+of+the + Video+Production+Diary\&open $=0 \&$ view $=$ simple \&phrase $=1 \&$ colu $\underline{\mathrm{mn}}=\mathrm{def}$ (Accessed on 13th November 2015 at 06:54 p.m.)

Miarso, Y. 2005. Menyemai Benih Teknologi Pendidikan. Jakarta: Prenada Media.

Rohmat (2010). Media Pembelajaran, Suatu Pengantar. Yogyakarta: Logung Pustaka.

Zhang, X. 2013.2003. International Journal of Arts and Commerce.Talking About Cultural Influence On Table Manners From Intercultural Adaption.Vol 2. No 3. ISSN 1929-7106. ElectronicBook.http://ijac.org.uk/images/frontImages/gallery/Vol._2_No._3/17 .pdf(Accessed on Thursday 22nd October 2015 at 10:30 p.m.). 